\title{
Effect of Cleaning the Annular Space on the Adhesion of the Cement Sheath to the Rock
}

\author{
Marcin Kremieniewski ${ }^{1, *(\mathbb{D})}$, Sławomir Błaż ${ }^{1} \mathbb{D}$, Stanisław Stryczek $^{2} \mathbb{D}$, Rafał Wiśniowski ${ }^{2}(\mathbb{D})$ and Andrzej Gonet ${ }^{2}$ \\ 1 Oil and Gas Institute—National Research Institute, 31-503 Kraków, Poland; blaz@inig.pl \\ 2 Department of Drilling and Geoengineering, Faculty of Drilling, Oil and Gas, AGH University of Science and \\ Technology, 30 Mickiewicza Ave., 30-059 Kraków, Poland; stryczek@agh.edu.pl (S.S.); \\ wisniows@agh.edu.pl (R.W.); gonet@agh.edu.pl (A.G.) \\ * Correspondence: kremieniewski@inig.pl
}

Citation: Kremieniewski, M.; Błaż, S. Stryczek, S.; Wiśniowski, R.; Gonet, A. Effect of Cleaning the Annular Space on the Adhesion of the Cement Sheath to the Rock. Energies 2021, 14, 5187. https://doi.org/10.3390/ en14165187

Academic Editor: Reza Rezaee

Received: 16 July 2021

Accepted: 17 August 2021

Published: 22 August 2021

Publisher's Note: MDPI stays neutral with regard to jurisdictional claims in published maps and institutional affiliations.

Copyright: (c) 2021 by the authors. Licensee MDPI, Basel, Switzerland. This article is an open access article distributed under the terms and conditions of the Creative Commons Attribution (CC BY) license (https:/ / creativecommons.org/licenses/by/ $4.0 /)$.
Abstract: Drilling boreholes in gas zones and in zones with the possibility of migration or gas exhalation requires a high index of well tightness. An important parameter determining the effectiveness of sealing the annular space is the adhesion of the cement sheath to the rock formation. Low values of adhesion of the cement sheath to the rock formation and to the casing surface result in the formation of uncontrolled gas flows. The lack of adhesion also reduces the stabilization of the pipe column. To obtain the required adhesion, the annular space should be properly cleaned. Thorough removal of filter cake from the drilling fluid increases adhesion and reduces gas migration from the annular space. Therefore, in this work, the authors focus on determining the effect of cleaning the annular space on the adhesion of the cement sheath to the rock formation. The results of the research work allow for further research on the modification of spacers and cement slurries in order to obtain the required increase in adhesion. The article presents the issues related to the preparation of the borehole for cementing by appropriate cleaning of the rock formation from the residue of the mud cake. During the implementation of the works, tests of cleaning the rock surface are performed. The obtained results are correlated with the results of adhesion on the rock-cement sheath cleaned of the wash mud cake contact. When analyzing the obtained test results, a relationship is found between the cleaning of the rock surface and the adhesion of the cement sheath to it.

Keywords: improving the sealing of the borehole; rational selection of drilling fluids; well cementing; cleaning the borehole; adhesion; cement sheath; spacer fluid

\section{Introduction}

\subsection{Purpose of the Work and Literature Background}

Cementing of the casing column is performed in order to seal the annular space, i.e., to isolate the gas, oil and aquifers levels. The lack of such tightness makes it possible to create out-of-pipe flows of reservoir media or prevent the exploitation of natural gas [1-4]. In order to properly insulate the annular space, the cement slurry is pressed in. After it is bonded to the rock formation and to the surface of the casing, it guarantees the required tightness. However, this tightness also depends on the adhesion of the cement sheath to the contact surface. According to the literature [5,6], good grip means that there is no gap or no free movement of two bodies in relation to each other. It is interpreted in the contact plane with simultaneous action of tearing, compressive or shear stresses from the outside $[5,7,8]$.

\subsection{Factors Influencing the Adhesion of the Cement Sheath}

When analyzing the conditions in the borehole, the resulting types and directions of force action in relation to the contact surface of the cement sheath and pipes are distinguished [9]. In the borehole, there are forces with the direction of action perpendicular to the contact surface and the forces acting in the direction parallel to these surfaces, analyzed later in this publication. These forces are caused by the elongation or contraction of the 
pipes due to temperature changes. They can also be the result of the formation of resistances preventing the mutual displacement of pipes [9-11]. The parameter of adhesion is the slip resistance determined in the tests by the vertical movement of the steel pipe or the rock core in the hardened cement slurry, as shown in Figure 1.

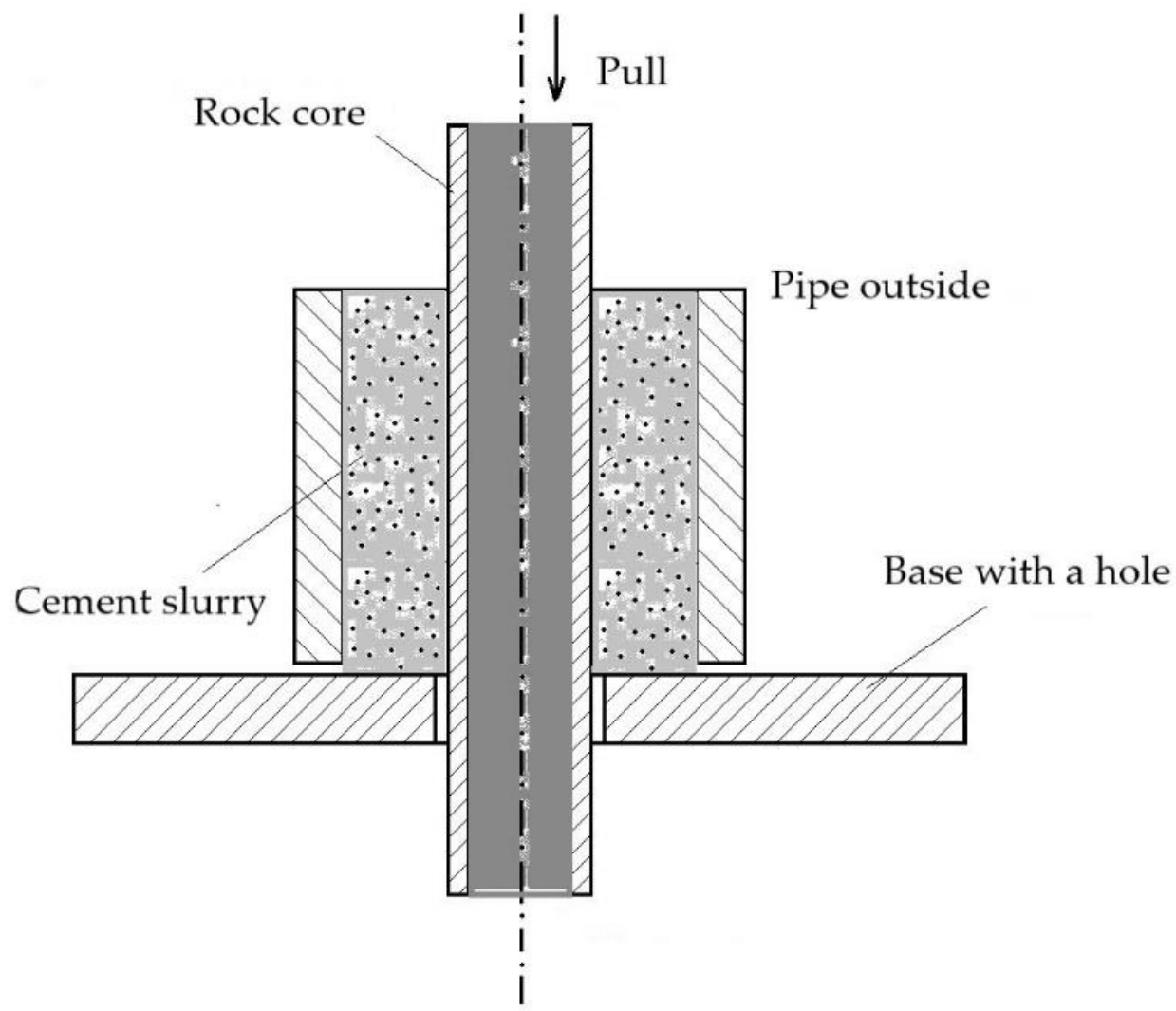

Figure 1. Scheme for determining the adhesion of a cement sheath to steel or rock formation.

The factors that affect the adhesion of the hardened cement slurry to the contact surface are mainly $[9,12-14]$ :

$\sqrt{ }$ Tight adhesion of the cement sheath to the contact surface;

$\sqrt{ }$ Positive volume increase of the setting cement slurry;

$\sqrt{ }$ Gelling of the cement slurry on contact with the hydrated subsurface layer of the rock formation;

$\sqrt{ } \quad$ The pressure exerted by the casing pipes on the setting cement slurry by cooling the pipes with the pumped liquids and then expanding them due to the temperature increase during the setting of the cement slurry;

$\sqrt{ }$ Adhesion forces between cement slurry and pipes;

$\sqrt{ }$ Bonding of the cement slurry to the surface of the pipes and the surface of the rock formation due to the penetration of slurry into the cavities resulting from the roughness of the contact surface.

In turn, the reduction of the adhesion value of the cement sheath to the contact surface is influenced by:

$\sqrt{ } \quad$ Shrinkage of cement slurry during setting;

$\sqrt{ }$ Fluctuations in pressure and temperature during the setting of the cement slurry resulting, inter alia, from closing the cement head after the completion of cementing and leaving the pipe column at the final pressure of the treatment;

$\sqrt{ }$ Injection into the borehole of a cold scrubber when drilling cement plug;

$\sqrt{ }$ Low surface roughness coefficient of pipes [15-18]. 
However, from the point of view of preparing the borehole for cementing, the nondisplaced mud layer has a significant influence on the adhesion of the cement sheath. It blocks the wetting of the surfaces in contact with the cement slurry due to the formation of adhesion forces at the interface [19]. Moreover, the unremoved mud cake after mixing with the cement slurry in the annular space reduces the mechanical strength of the cement sheath [20-23]. It should be borne in mind that obtaining adequate tightness at the contact of the cement sheath with the rock formation is influenced not only by the close adhesion of individual layers (cement slurry to the wall of the borehole). Adhesion at the contact of these layers also shows a strong influence [24,25]. Only the combination of both coface and adhesion (adhesive and mechanical) allows the total to obtain the required contact tightness effect of the cement sheath and the rock formation. Obtaining proper coface is not a problem because the cement slurry with appropriately designed rheological parameters penetrates the rock mass discontinuities resulting from drilling [8,26-28]. However, obtaining the appropriate values of the second parameter, which is adhesion, requires appropriate preparation of the annular space.

\subsection{Preparation of the Borehole for Cementing}

In the first stage, preparation of the borehole for cementing consists in lowering the rheological parameters of the washer during rinsing $[29,30]$. Then, the spacer (washing liquid) is pumped into the annular space in order to displace the drilling fluid and the mud residue [31-33]. A very advantageous condition is that the casing column and the drilled rock formation are moistened with the spacer. Such action improves the setting of the cement slurry pumped over these liquids [34-36]. In order to thoroughly remove the drilling fluid residues, washings consisting of a mixture of dispersants and surfactants are used. The parameters of these spacers must be very precisely designed [37-41]. A number of factors influence the efficiency of washing mud cake. These are, among others, contact time of the spacer, spacer pumping rate, chemical composition of the spacer, concentration of the agents used to prepare the spacer. The type of surface from which the mud cake is removed, the type of drilling mud used for drilling and its technological parameters as well as borehole conditions (temperature and pressure) are also important [37,42-46]. It has been observed that obtaining an adequate cleaning of the annular space sometimes contributes to the improvement of the tightness of the borehole.

The aim of the study is to determine the effect of cleaning the annular space on the adhesion of the cement sheath to the rock formation. In order to obtain the required result, it is necessary to thoroughly study the conditions in the cement sheath-rock formation system. The obtained results are helpful in indicating the leading factor (adhesion or adhesion) which determines the tightness. This allows to determine the effect of cleaning the annular space on adhesion and introduce modifications to improve adhesion and obtain adequate tightness of the borehole.

\section{Materials and Methods}

\subsection{Materials}

Four spacers and water as a control liquid were used to determine the effect of cleaning the annular space on the adhesion of the cement sheath to the rock. The first liquid is a $0.5 \%$ solution of SL372-ethoxylated alcohol C12-C15 (anionic surfactant from alkyl ether sulfate group). The second liquid is a solution of $0.5 \%$ RL22-ethoxylated alcohol C12-C14 (nonionic surface-active compound used as emulsifier). The third liquid is CD-fatty alcohol alkyl polyglucoside C8-C10. The fourth liquid called RL80 is ethoxylated alcohol C12-C14 (surface active agent used for wetting and as a non-ionic component of emulsifiers).

CEM I 42.5R Portland cement was used to prepare the cement slurry. This cement is composed of $2.65 \% \mathrm{SO}_{3}$ and $0.064 \% \mathrm{Cl}^{-}$. Materials were also used to regulate the parameters of the cement slurry. PSP 046 plasticizer is a dispersant based on modified lignosulfonates and naphthalene with a bulk density of $440-550 \mathrm{~kg} / \mathrm{m}^{3}$ and a $\mathrm{pH}$ value ranging from 6.6 to 8.5. In order to remove air from the cement slurry, a defoaming agent 
was used-a mixture of esters of unsaturated fatty acids and refined hydrocarbons. The start also included an antifiltrating agent and setting accelerator. Latex, which is a water dispersion of styrene-butadiene copolymer, was used to reduce the porosity of the cement sheath. Additionally, a latex stabilizer was added to the cement slurry. The matrix of the cement sheath was sealed with a $10 \%$ addition of microcement, which comes from Halliburton Micro Matrix. This type of microcement has grains smaller than or equal to $10 \mu \mathrm{m}$, and its specific surface area is approximately $1380 \mathrm{~m}^{2} / \mathrm{kg}$. The percentage of means to prepare the cement slurry is summarized in Table 1.

Table 1. Recipe and parameters of the cement slurry used in the test of adhesion on the hardened cement slurry-rock contact.

\begin{tabular}{cc}
\hline Ingredients & \% by Mass of Cement \\
\hline Water-cement ratio & 0.46 \\
Plasticizer & 0.2 \\
Latex & 8.0 \\
Stabilizer & 1.0 \\
Defoaming agent & 0.48 \\
Antifiltrating agent & 0.22 \\
Setting accelerator & 4.2 \\
Microcement & 10.0 \\
Cement CEM I 42.5R & 100.0 \\
\hline
\end{tabular}

All components in \% by mass of cement.

\subsection{Methods}

2.2.1. Preparation of the Spacer (Washing Liquid)

To prepare the spacer, the following wre used:

$\sqrt{ }$ The control spacer is water;

$\sqrt{ }$ Liquid No. 1 to $0.5 \%$ solution SL372-ethoxylated alcohol C12-C15 (anionic surfactant from alkyl ether sulfate group);

$\sqrt{ }$ Liquid No. 2 is a $0.5 \%$ solution of RL22-ethoxylated alcohol C12-C14 (non-ionic surface-active compound used as emulsifier);

$\sqrt{ } \quad$ Liquid No. 3 to $0.5 \%$ solution CD-fatty alcohol alkyl polyglucoside C8-C10;

$\sqrt{ }$ Liquid No. 4 is a $0.5 \%$ solution of RL80-ethoxylated alcohol C12-C14 (surface active agent used for wetting and as a non-ionic component of emulsifiers).

To prepare the spacer, a certain amount of water was measured with a measuring cylinder. The water was poured into the mixer. The rotation speed was then set to $500 \mathrm{rpm}$ and the specified amount of rinse aid was added.

\subsubsection{Preparation of the Cement Slurry}

For the effect of cleaning the annular space on the adhesion of the cement sheath to the rock, the samples of the cores after washing were sealed with cement slurry. The cement slurry was prepared as follows. A certain amount of water was measured out with a measuring cylinder. The water was placed in the mixer. The speed was set to $1600 \mathrm{rpm}$. The cement slurry agents were added to the mixing water and mixed for $10 \mathrm{~min}$. Later, loose materials (microcement, cement) were dosed into the mixing water with chemicals and mixed for another $20 \mathrm{~min}$. Mixing at low speed reflects slurry at well conditions.

\subsubsection{Experimental Procedures}

The properties of the cement slurry were tested in accordance with the standard:

$\sqrt{ }$ PN-EN ISO 10426-2. Oil and gas industry. Cements and materials for cementing holes. Lot 2: Testing of drilling cements. These tests include the following measurements: slurry density, filtration and thickening time. 
The adhesion test was carried out according to the standard.

$\sqrt{ }$ PN-EN 196-1: 2006 Cement testing methods. Compressive strength determination

The test plan was adapted to the needs of the tests, the results of which allow to determine the effect of cleaning the annular space on the adhesion of the cement sheath to the rock. The drilling fluid flow simulator constructed at the Oil and Gas Institute-National Research Institute (Patent P.423842) was used for the tests. The device (Figure 2) allows to simulate the mud flow in the annular space. In this way, a washing mud cake was formed on the surface of the rock cores. The mud cake removal tests were carried out on four selected spacers, which were pumped at a rate of $11.2 \mathrm{~L} / \mathrm{min}$. This gives a Reynolds number of 3100 . Water was used as the base spacer to determine the deposit removal checkpoint. The washing time was $4 \mathrm{~min}$. The samples on which the mud cake was formed were three sandstone cores with an outer diameter of $25 \mathrm{~mm}$ and a length of $60 \mathrm{~mm}$. They were fixed in a tripod inside a PVC pipe (Figure 2-left part of the photo) in a drilling fluid flow simulator.

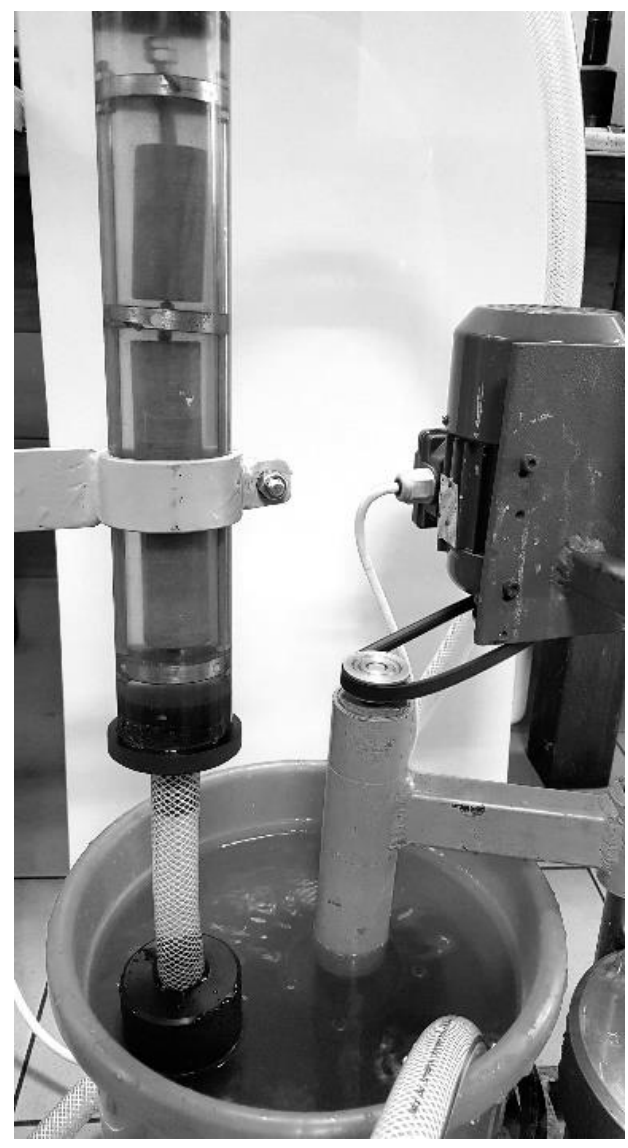

Figure 2. Drilling fluid flow simulator-view of the spacer pumping device.

In the first stage, the degree of surface cleaning of the cores was determined by measuring the mass of the mud cake remaining on the cores after washing. The cores reflect the annular space of the borehole. The mass of the core before mud cake formation $\left(m_{R}\right)$ was determined, then the core with the mud cake $\left(m_{\text {Ros }}\right)$ was weighed, and after pumping the spacer, the weight of the rock core with the residue of the spacer was determined again after pumping the spacer $\left(m_{R p o}\right)$. On the basis of the obtained results, the percentage effectiveness of the mud cake removal from the core surface was calculated according to formula: 


$$
\%=100 \cdot \frac{m_{\text {Ros }}-m_{R p o}}{m_{\text {Ros }}-m_{R}}
$$

where:

$\%$-percent of sediment washout;

$m_{R}-$ core mass before the test (without mud cake);

$m_{\text {Ros }}$ - core mass with mud cake;

$m_{R p o}$ - mass of the core with the residue of the mud cake (after washing);

In the tests, a mud cake from the PSK borehole was used to create a mud, which contained contaminants from the interval drilled into a 7-inch pipe section. Four spacers and a standard liquid-water spacer were used to determine the degree of deposit removal. Table 2 shows the results of the mud cake removal tests.

Table 2. The results of the research on the efficiency of the mud cake removal from the core surface and the adhesion of the cement sheath to the rock formation.

\begin{tabular}{|c|c|c|c|c|c|c|}
\hline Spacer & Measurement No. & Water & Spacer 1 & Spacer 2 & Spacer 3 & Spacer 4 \\
\hline \multirow{3}{*}{ Core weight before test $m_{R}, \mathrm{~g}$} & 1 & 68.65 & 68.64 & 68.65 & 68.66 & 68.66 \\
\hline & 2 & 68.68 & 68.65 & 68.64 & 68.64 & 68.66 \\
\hline & 3 & 68.65 & 68.65 & 68.66 & 68.65 & 68.65 \\
\hline \multirow{3}{*}{ Core weight after mud $m_{R o s}, \mathrm{~g}$} & 1 & 72.58 & 72.52 & 72.5 & 72.47 & 72.44 \\
\hline & 2 & 72.55 & 72.5 & 72.52 & 72.4 & 72.89 \\
\hline & 3 & 72.54 & 72.44 & 72.47 & 72.43 & 72.75 \\
\hline \multirow{3}{*}{$\begin{array}{l}\text { Core weight after spacer } \\
\qquad m_{R p o}, \mathrm{~g}\end{array}$} & 1 & 70.44 & 69.52 & 69.49 & 69.65 & 69.44 \\
\hline & 2 & 70.38 & 69.6 & 69.49 & 69.72 & 69.43 \\
\hline & 3 & 70.37 & 69.58 & 69.47 & 69.72 & 69.4 \\
\hline \multirow{3}{*}{$\begin{array}{l}\text { Washing percentage, } \\
\%\end{array}$} & 1 & 54.45 & 77.32 & 78.18 & 74.02 & 79.37 \\
\hline & 2 & 56.07 & 75.32 & 78.09 & 71.28 & 81.8 \\
\hline & 3 & 55.78 & 75.46 & 78.74 & 71.69 & 81.71 \\
\hline $\begin{array}{l}\text { Washing percentage } \\
\text { (removal of mud cake) } \\
\text { average value, } \\
\%\end{array}$ & $\bar{x}$ & 55.44 & 76.04 & 78.34 & 72.33 & 80.96 \\
\hline $\begin{array}{l}\text { Percentage increase in } \\
\text { washing efficiency } \\
\text { compared to the base value } \\
\text { (washing with water), \% }\end{array}$ & $\bar{x}$ & 0.00 & 37.16 & 41.31 & 30.47 & 46.03 \\
\hline $\begin{array}{l}\text { The average value of the adhesion } \\
\text { of the cement sheath to the rock, } \\
\qquad \mathrm{MPa}\end{array}$ & $\bar{x}$ & 0.696 & 0.928 & 0.957 & 0.870 & 0.986 \\
\hline $\begin{array}{l}\text { Percentage of adhesion increase in } \\
\text { relation to the base value (adhesion } \\
\text { after washing with water), \% }\end{array}$ & $\bar{x}$ & 0.00 & 33.33 & 37.50 & 25.00 & 41.67 \\
\hline $\begin{array}{l}\text { The difference between the } \\
\text { percentage increase in washing } \\
\text { efficiency and the percentage } \\
\text { increase in adhesion, } \\
\%\end{array}$ & $\bar{x}$ & 0.00 & 3.83 & 3.81 & 5.47 & 4.36 \\
\hline
\end{tabular}

In the second stage of the research, the values of adhesion at the contact between the cement sheath and the rock core were determined. The tests were carried out for previously washed core samples and for the control sample, i.e., the core washed with water as the spacer. In order to determine the adhesion of the cement sheath to the sandstone core, after the mud cake was formed on it, and then, after washing with selected liquids, it was placed in a mold (Figure 3 ) and poured with cement slurry (Figure 4). 


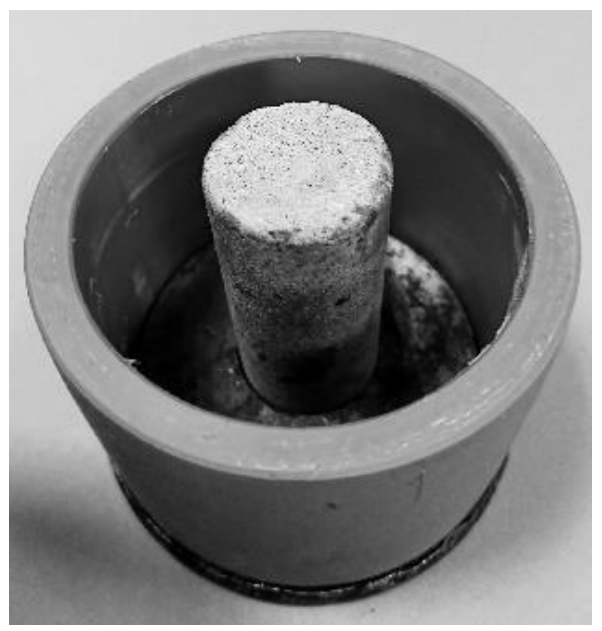

Figure 3. Core sample ready to be filled with cement slurry.

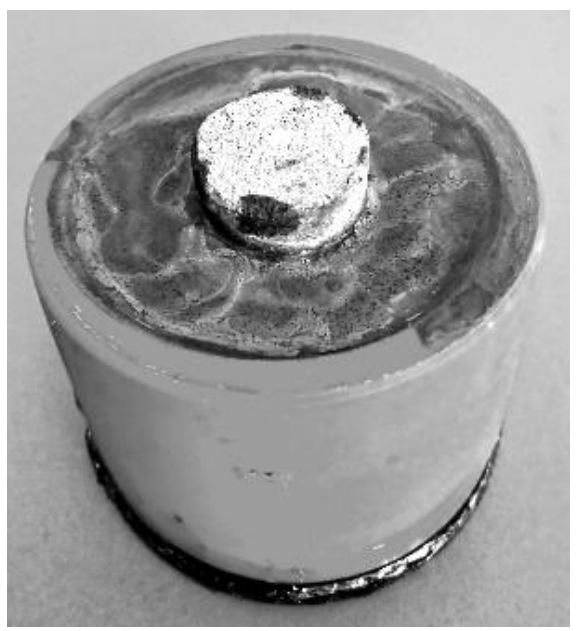

Figure 4. Sample prepared for adhesion tests.

After $48 \mathrm{~h}$ of hydration, adhesion tests were performed on the contact between the hardened cement slurry and the rock core (cleaned of the previously produced mud cake). The adhesion test consists of placing a core sample sealed with cement slurry between the plates of a testing machine (Figure 5) and determining the breaking strength of adhesion on the hardened cement slurry-rock contact under the influence of a load applied to the sample.

The adhesion $(\mathrm{MPa})$ on the contact between the hardened cement slurry and the rock core was calculated according to the Formula (2):

$$
\sigma_{p}=\frac{P}{s} \cdot 10^{-3}[\mathrm{MPa}]
$$

where:

$\sigma_{p}$ - contact adhesion hardened cement slurry-rock core (MPa),

$P$-pressure force causing the connection to be broken at the contact of the hardened cement slurry with the rock $(\mathrm{kN})$ - original record from a testing machine, $s$ - contact surface of the rock sample with the cement slurry $\left(\mathrm{m}^{2}\right)$. 


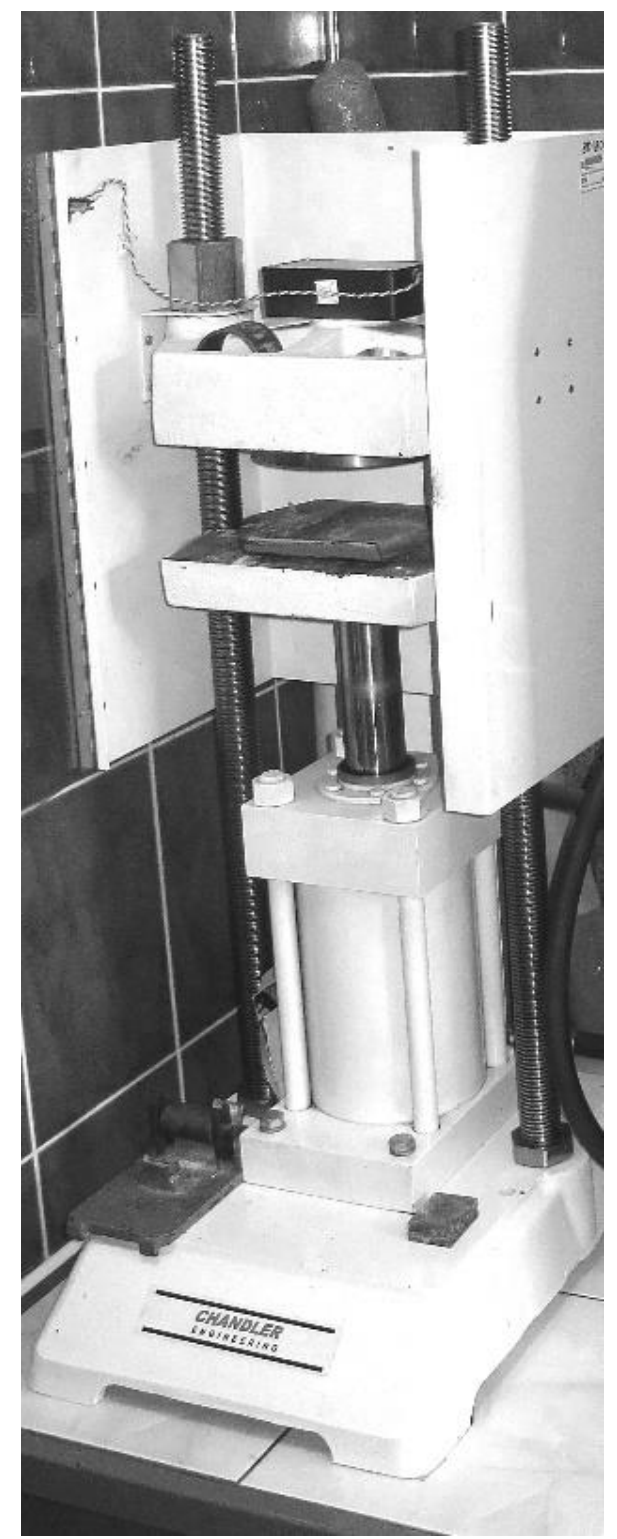

Figure 5. Machine for testing strength and adhesion.

The contact force $(P)$ was read from the testing machine. The contact surface of the rock with the hardened cement slurry was equal to the value of the outer surface area of the core and the height of the cement slurry in the mold. Figure 6 shows the dimensions necessary to determine the contact surface of the rock with the hardened cement slurry. In order to obtain reliable results, all tests were carried out using a cement slurry of the same composition. The results of the adhesion tests obtained on the contact between the hardened cement slurry and the rock core are presented in Table 2.

$$
s=\pi \cdot d \cdot h\left[\mathrm{~m}^{2}\right]
$$

where:

$d$-core diameter $(\mathrm{m})$ for the conducted research is equal to $25 \mathrm{~mm}=0.025 \mathrm{~m}$;

$h$-the height of the cemented part of the core for the conducted research is $44 \mathrm{~mm}=0.044 \mathrm{~m}$. 


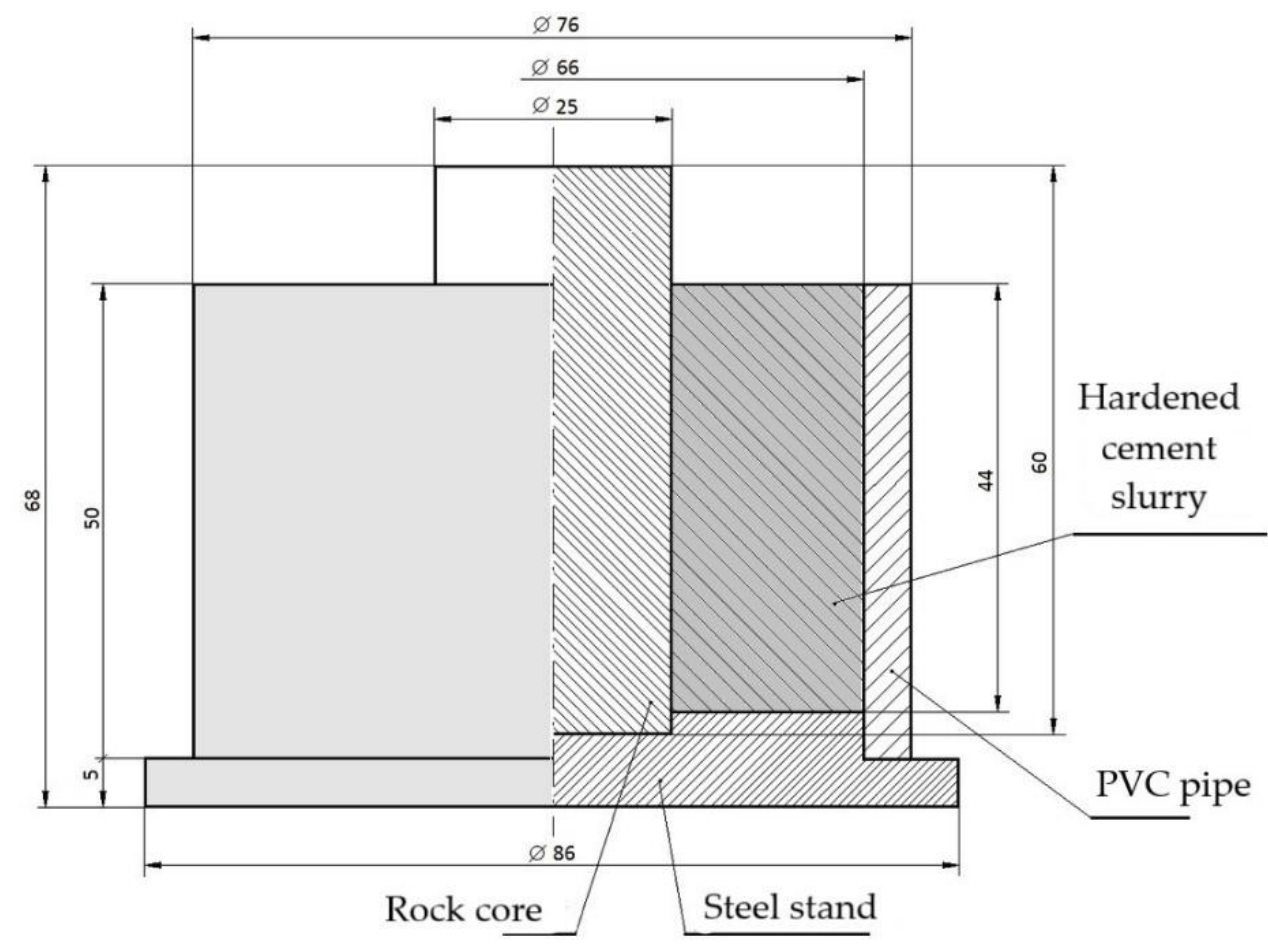

Figure 6. Diagram showing the core sample placed in the adhesion test mold.

\section{Results}

The study of the mud cake removal efficiency begins with the determination of the value of the mud cake removal from the core surface with water (control test). This sample achieved a 55.44\% removal of mud cake from the core surface. Then, tests of mud cake removal by various spacers were carried out. The obtained values of mud cake removal range from $72.33 \%$ for washing the cores with the spacer No. 3 to the maximum value, which is $80.96 \%$ after using the washing spacer No. 4 (Table 1 ). On the basis of the obtained results, the percentage increase in the washing efficiency in relation to the control sample is estimated at 55.44\% (washing with water). The range of percentage increase in the mud cake leaching efficiency in relation to the base value, presented in Table 2, ranges from $30.47 \%$ to $46.03 \%$. The results of the percent mud cake removal and the increase compared to the baseline value are summarized in Table 2 and Figure 7.

Another test is to determine the adhesion on the contact between the hardened cement slurry and the rock core cleaned of the produced washing mud cake. As in the previous test, first the adhesion of the control sample was determined. This is the adhesion after washing the core set with water as the spacer. The average of the adhesion values is $0.696 \mathrm{MPa}$ (Table 2). Then, adhesion tests were carried out for samples washed by selected spacers. The average values of adhesion range from $0.87 \mathrm{MPa}$ for the sample after the application of spacer No. 3 to the maximum value of adhesion, which is $0.986 \mathrm{MPa}$ after washing the samples with the spacer No. 4 (Table 2 and Figure 7). The percentage increase in adhesion compared to the control sample ranges from $25 \%$ (spacer No. 3) to $41.67 \%$ (spacer No. 4). The results are presented in Table 2 and in Figure 7.

Additionally, an important interpretation is the difference between the percentage increase in the washing efficiency and the percentage increase in adhesion presented in the last row of Table 2. Values ranging from $3.81 \%$ to $5.47 \%$ were obtained. For such an interpretation, the percentage increase of the analyzed parameters (washing efficiency and adhesion) in relation to the base value was selected. This made it possible to determine the convergence of the analyzed values. 


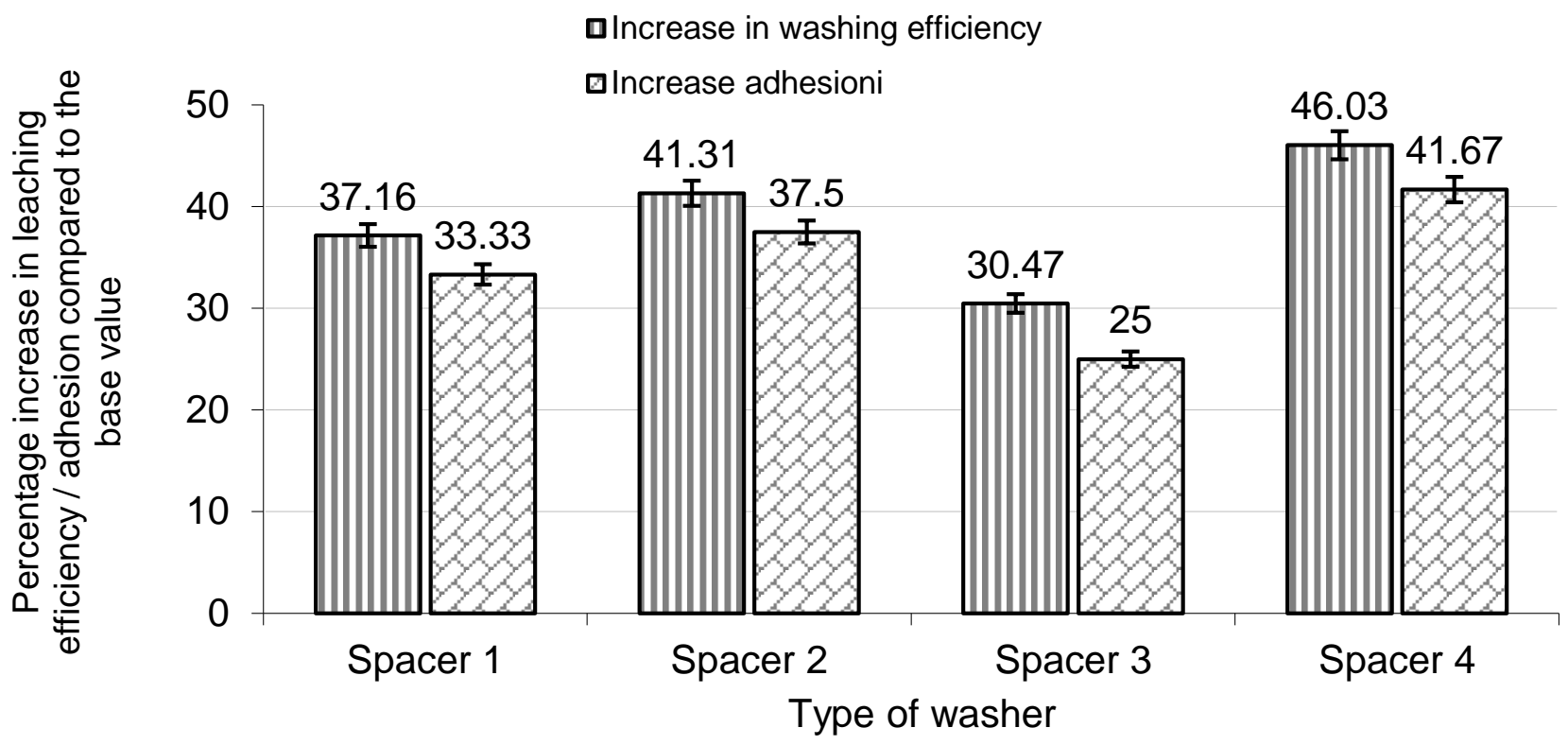

Figure 7. List of the percentage increase of the analyzed parameters (the effectiveness of the removal of mud cake and adhesion on the contact between the hardened cement slurry-the rock core) in relation to the base value.

When analyzing the test results, it is stated that the values of the mud cake removal efficiency, i.e., the efficiency of cleaning the annular space, is proportional to the adhesion of the cement sheath to the rock formation. Therefore, a correlation analysis was performed to determine the degree of convergence between the compared features on the basis of the Pearson's correlation coefficient. Pearson's correlation coefficient is calculated on the basis of Formula (4), then according to Formula (5), the covariance (cov) was calculated, which determines the linear relationship between the analyzed variables $\mathrm{x}$ and $\mathrm{y}$, and the maximum likelihood estimator Sdx, Sdy giving the smallest deviation values (Formulas (6), (7), and Table 3). In the final step, the linear determination index (8) was calculated, which informs about the percentage of linearly expressed variability of the dependent variable by the independent variable. The interpretation of the strength of the correlation relationships is as follows:

Pearson's correlation coefficient:

$>$ below 0.2 -weak correlation (practically no relationship);

$>\quad 0.2-0.4-$ low correlation (clear relationship);

$>\quad 0.4-0.6$ - moderate correlation (significant relationship);

$>\quad 0.6-0.8$ - high correlation (significant dependence);

$>\quad 0.8-0.9$ - very high correlation (very high correlation);

$>$ 0.9-1.0-total correlation (practically full relationship).

$$
r_{x, y}=\frac{\operatorname{cov}(x, y)}{S d_{x} \cdot S d_{y}}
$$

where:

$x$-percentage values of elution (removal of mud cake) mean values (\%); $y$-value of the average adhesion of the cement sheath to the rock (MPa);

$S d_{x}, S d_{y}$-maximum likelihood estimators;

$n$-number of attempts. 


$$
\begin{aligned}
\operatorname{cov}(x, y) & =\frac{\sum\left(x_{i}-\bar{x}\right)\left(y_{i}-\bar{y}\right)}{n} \\
S d_{x} & =\sqrt{\frac{\sum\left(x_{i}-\bar{x}\right)^{2}}{n}} \\
S d_{y} & =\sqrt{\frac{\sum\left(y_{i}-\bar{y}\right)^{2}}{n}} \\
W D & =r_{x y}{ }^{2} \cdot 100 \%
\end{aligned}
$$

After substituting to formulas

$$
\begin{gathered}
\operatorname{cov}(x, y)=\frac{4.6623}{5}=0.930517 \\
S d_{x}=\sqrt{\frac{409.207}{5}=9.05} \\
S d_{y}=\sqrt{\frac{0.053}{5}}=0.10 \\
r_{x, y}=\frac{0.930517}{9.05 \cdot 0.10}=0.997623 \\
r=0.99 \in\langle 0.9 ; 1.0) \\
W D=(0.997623)^{2} \cdot 100 \% \\
W D=99.53 \%
\end{gathered}
$$

Table 3. Calculation data from the correlation of the mud cake removal efficiency to the adhesion of the cement sheath in contact with the rock formation.

\begin{tabular}{cccccccc}
\hline $\boldsymbol{n}$ & $\boldsymbol{x}_{\boldsymbol{i}}$ & $\boldsymbol{y}_{\boldsymbol{i}}$ & $\left(\boldsymbol{x}_{\boldsymbol{i}}-\overline{\boldsymbol{x}}\right)$ & $\left(\boldsymbol{y}_{\boldsymbol{i}}-\overline{\boldsymbol{y}}\right)$ & $\left(\boldsymbol{x}_{\boldsymbol{i}}-\overline{\boldsymbol{x}}\right)\left(\boldsymbol{y}_{\boldsymbol{i}}-\overline{\boldsymbol{y}}\right)$ & $\left(\boldsymbol{x}_{\boldsymbol{i}}-\overline{\boldsymbol{x}}\right)^{2}$ & $\left(\boldsymbol{y}_{\boldsymbol{i}}-\overline{\boldsymbol{y}}\right)^{2}$ \\
\hline 1 & 55.44 & 0.696 & -17.2 & -0.2 & 3.29 & 295.22 & 0.04 \\
2 & 76.04 & 0.928 & 3.4 & 0.0 & 0.14 & 11.68 & 0.00 \\
3 & 78.34 & 0.957 & 5.7 & 0.1 & 0.40 & 32.70 & 0.00 \\
4 & 72.33 & 0.87 & -0.3 & 0.0 & 0.01 & 0.09 & 0.00 \\
5 & 80.96 & 0.986 & 8.3 & 0.1 & 0.82 & 69.52 & 0.01 \\
& $\Sigma=363.11$ & $\Sigma=4.437$ & & & $\Sigma=4.653$ & $\Sigma=409.207$ & $\Sigma=0.053$ \\
\hline
\end{tabular}

$x_{i}$-readings of the percentage of elution (removal of mud cake) average values (\%). $y_{i}$-value of the average adhesion of the cement sheath to the rock (MPa). Average values, $\bar{x}=72.6, \bar{y}=0.90$.

Based on the correlation analysis of the obtained results of the research, the percentage increase in the effectiveness of mud cake removal to the percentage increase in adhesion, a strong match of the analyzed features is found. The value of linear regression R2 is in the range of the total correlation (Figure 8). Correlation analysis confirms the strong correlation between the increase in adhesion and the effectiveness of the removal of mud cake from the surface of the rock formation. The confirmation of the dependence of the analyzed features obtained on the basis of the test results allows us to state how strong the adhesion growth will be depending on the increase in the efficiency of cleaning the annular space. Additionally, the reverse relationship, i.e., how the efficiency of cleaning the space will increase on the basis of the obtained results of adhesion of the hardened cement slurry to the rock formation. 


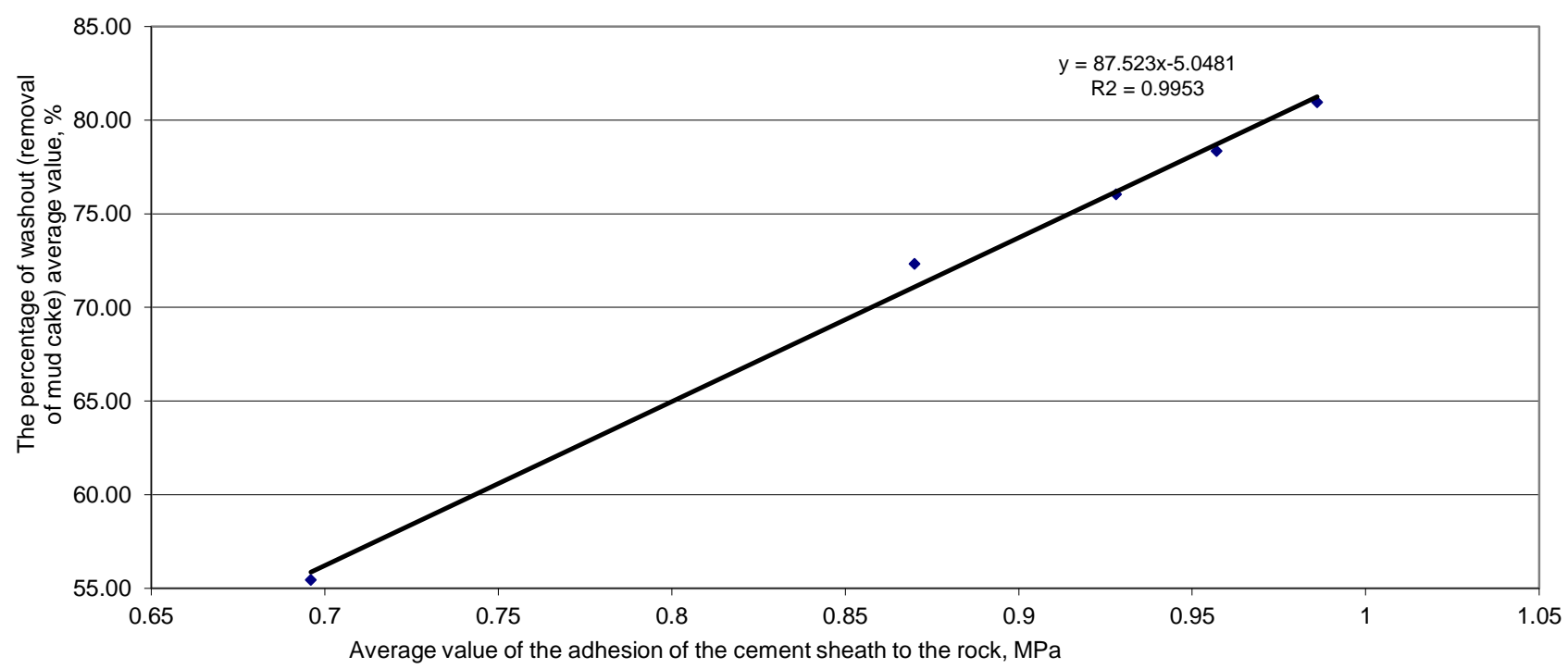

Figure 8. The relationship between the efficiency of mud cake removal and the adhesion of the cement sheath on contact with the rock formation.

\section{Discussion}

The performed tests confirmed the necessity to properly prepare the annular space for the cementing procedure by effectively removing the residues of the washing mud cake. It was found that one of the most important factors determining the tightness and durability of the cement sheath is the proper cleaning of the annular space from the mud cake. A number of other factors that determine the effectiveness of sealing should be taken into account. These include the parameters of the drilling mud used for drilling, the composition, the type and parameters of the cement slurry, and the geological and technical conditions. Only a comprehensive analysis of all factors contributes to the expected results of work on improving the effectiveness of cementing.

\section{Conclusions}

Based on the research on the effect of cleaning the annular space on the adhesion of the cement sheath to the formation, it is concluded that:

1. The use of water for washing the geological structure from the washing mud cake formed on its surface results in the removal of approx. $55 \%$ of the washing mud cake.

2. Spacers selected for testing remove the washing mud cake formed on the surface of the cores in the range from $72.3 \%$ to $81 \%$.

3. The obtained values of cleaning the surface of the core represent an increase in removal from $30.5 \%$ to $46 \%$ compared to cleaning the surface of the cores with water, which is used as the standard spacer.

4. The adhesion of the hardened cement slurry formulated for the tests to the rock core washed with water is $0.7 \mathrm{MPa}$.

5. The use of spacer selected for the purpose of testing allows to obtain adhesion on the contact between the hardened cement slurry-rock formation in the range from 0.87 to $0.99 \mathrm{MPa}$.

6. The percentage increase in adhesion compared to the base value ranges from $25 \%$ to $42 \%$.

7. The difference between the percentage increase in washing efficiency and the percentage increase in adhesion shall not exceed the value of $5.5 \%$.

8. On the basis of the obtained test results and the correlation analysis carried out, a very strong relationship is found between the cleaning of the annular space from the slurry mud cake and the adhesion of the hardened slurry to the rock formation. 
It should be borne in mind that despite the strong correlation between the cleaning of the annular space from the drilling mud cake and the adhesion of the cement sheath to the rock formation, a number of additional parameters determining the effectiveness of sealing the borehole should be taken into account. Therefore, each time before the cementing procedure is performed, specialized laboratory tests are carried out for specific geological and technological conditions.

Author Contributions: Data curation, M.K.; Formal analysis, M.K., S.B., S.S. and R.W.; Funding acquisition, M.K.; Investigation, M.K., S.S., R.W. and A.G.; Methodology, M.K. and S.S.; Project administration, S.B. and R.W.; Software, S.B., R.W. and A.G.; Validation, S.S., R.W. and A.G.; Visualization, S.B., S.S. and A.G.; Writing—original draft, M.K.; Writing—review \& editing, S.S., R.W. and A.G. All authors have read and agreed to the published version of the manuscript.

Funding: The work was financially supported by Ministry of Science and Higher Education Warsaw (Internal order Oil and Gas Institute-National Research Institute Project No. 0015/KW/21).

Institutional Review Board Statement: Not applicable.

Informed Consent Statement: Not applicable.

Data Availability Statement: Not applicable.

Acknowledgments: The author thanks the anonymous reviewers for their constructive comments and the editor for handling the paper.

Conflicts of Interest: The author declares no conflict of interest.

\section{Nomenclature}

Symbol
\%
$m_{R}$
$m_{\text {Ros }}$
$m_{\text {Rpo }}$
$d$
$h$
$x$
$y$
$S d_{x}, S d_{y}$
$n$
$x_{i}$
$y_{i}$
$\mathrm{MPa}$
$\mathrm{KN}$

\section{Explanation}

percent of sediment washout;

core mass before the test (without mud cake);

core mass with mud cake;

mass of the core with the residue of the mud cake (after washing);

core diameter $(\mathrm{m})$ for the conducted research is equal to $25 \mathrm{~mm}=0.025 \mathrm{~m}$;

the height of the cemented part of the core for the conducted research is $44 \mathrm{~mm}=0.044 \mathrm{~m}$;

percentage values of elution (removal of mud cake) mean values (\%);

value of the average adhesion of the cement sheath to the rock (MPa);

maximum likelihood estimators;

number of attempts;

readings of the percentage of elution (removal of mud cake) average values (\%);

value of the average adhesion of the cement sheath to the rock $(\mathrm{MPa})$;

megapascal;

kilonewton.

\section{References}

1. Kremieniewski, M. Cleaning of the casing string before cementation, based on research using a rotational viscometer. Nafta-Gaz 2018, 74, 676-683. [CrossRef]

2. Mitchell, R.F.; Miska, S. Fundamentals of Drilling Engineering; Spe Textbook Series; Society of Petroleum Engineers: DallaS, TX, USA, 2011; Volume 12, ISBN 978-1-55563-207-6. Available online: https:/ / store.spe.org/Fundamentals-of-Drilling-EngineeringP468.aspx (accessed on 5 May 2021).

3. Kremieniewski, M.; Rzepka, M.; Stryczek, S.; Wiśniowski, R. Comparison of Gas Migration Test and Building Structural Strength of Slurry in the Aspect of Limiting Gas Invasion. AGH Drill. Oil Gas 2016, 33, 595-608. [CrossRef]

4. Kremieniewski, M.; Wiśniowski, R.; Stryczek, S.; Orłowicz, G. 2021 Possibilities of Limiting Migration of Natural Gas in Boreholes in the Context of Laboratory Studies. Energies 2021, 14, 4251. [CrossRef]

5. Kremieniewski, M.; Stryczek, S. Zastosowanie cementu wysokoglinowego do sporządzania zaczynów uszczelniających w technologiach wiertniczych. Cem. Wapno Beton 2019, 3, 215-226.

6. Sauer, C.W. Mud Displacement During Cementing: A State of the Art. JPT: 1987. Available online: https://onepetro.org/JPT/articleabstract/39/09/1091/73826/Mud-Displacement-During-Cementing-State-of-the-Art (accessed on 5 May 2021). 
7. Nelson, E.B. Well Cementing; Schlumberger Educational Service: Houston, TX, USA, 1990. Available online: https://books.google. $\mathrm{pl} /$ books?hl=pl\&lr=\&id=1TRGZEnXOKMC\&oi=fnd\&pg=PP1\&dq=7.\%09Nelson, +E.B.+\%5Bet+al.\%5D,+Well+Cementing\% 3B+Schlumberger+Educational+Service:+Houston, +TX,+USA,+1990\&ots=gnpCi0ZE-1\&sig=ByhWpqGDzUc8vVRGGAuhQ7 OvRWw\&redir_esc $=\mathrm{y} \# \mathrm{v}=$ onepage\&q\&f$=$ false (accessed on 9 August 2021).

8. Lavrov, A.; Torsæter, M. Physics and Mechanics of Primary Well Cementing; Springer International Publishing: Houston, TX, USA, 2016; ISBN 978-3-319-43165-9. Available online: https://www.springer.com/gp/book/9783319431642 (accessed on 9 August 2021).

9. Habrat, S.; Raczkowski, J.; Zawada, S. Technika i Technologia Cementowań w Wiertnictwie; Wydawnictwa Geologiczne: Warsaw, Poland, 1980.

10. McLean, R.H.; Manry, C.W.; Whitaker, W.W. Displacement Mechanics in Primary Cementing. J. Pet. Technol. 1967, 19, 251-260. [CrossRef]

11. Zhang, F.; Miska, S.; Yu, M.; Ozbayoglu, E.; Takach, N.; Osgouei, R.E. Is Well Clean Enough? A Fast Approach to Estimate Hole Cleaning for Directional Drilling. In Proceedings of the SPE/ICoTA Coiled Tubing \& Well Intervention Conference \& Exhibition, The Woodlands, TX, USA, 24 March 2015. [CrossRef]

12. Knez, D.; Gonet, A.; Macuda, J.; Stryczek, S. Selected Issues of Wellbore Hydraulics and Cementing; AGH University of Science and Technology Press: Cracow, Poland, 2017; ISBN 978-83-7464-885-1. Available online: https://www.wydawnictwoagh.pl/pliki/26 5960783.pdf (accessed on 9 August 2021).

13. Kremieniewski, M. Recipe of Lightweight Slurry with High Early Strength of the Resultant Cement Sheath. Energies 2020, 13, 1583. [CrossRef]

14. Bizhani, M.; Corredor, F.E.R.; Kuru, E. Quantitative Evaluation of Critical Conditions Required for Effective Hole Cleaning in Coiled-Tubing Drilling of Horizontal Wells. SPE Drill. Compl. 2016, 31, 188-199. [CrossRef]

15. Stryczek, S.; Wiśniowski, R.; Uliasz-Misiak, B.; Złotkowski, A.; Kotwica, Ł.; Rzepka, M.; Kremieniewski, M. Studia nad doborem zaczynów uszczelniających w warunkach wierceń w basenie pomorskim. Wydaw. AHG Kraków 2016, 1-232. Available online: https:/ / www.wydawnictwoagh.pl/STUDIA-NAD-DOBOREMZACZYNOW-USZCZELNIAJACYCHW-WARUNKACHWIERCENW-BASENIE-POMORSKIM; s,karta,id,1172 (accessed on 9 August 2021).

16. Stryczek, S.; Wiśniowski, R.; Gonet, A.; Rzyczniak, M.; Sapińska-Śliwa, A. Wpływ wybranych superplastyfikatorów na właściwości reologiczne zaczynów cementowych stosowanych podczas cementowania kolumn rur okładzinowych w otworach wiertniczych. Przemyst Chem. 2018, 97, 903-905. [CrossRef]

17. Kremieniewski, M.; Rzepka, M. Przyczyny i skutki przepływu gazu w zacementowanej przestrzeni pierścieniowej otworu wiertniczego oraz metody zapobiegania temu zjawisku. Nafta-Gaz 2016, 9, 722-728. [CrossRef]

18. Kremieniewski, M. Ultra-Lightweight Cement Slurry to Seal Wellbore of Poor Wellbore Stability. Energies 2020, 13, 3124. [CrossRef]

19. Zima, G. Wpływ właściwości płuczek wiertniczych na jakość cementowania w gazonośnych poziomach miocenu. Nafta-Gaz 2014, 12, 899-907.

20. Kremieniewski, M. Korelacja skuteczności usuwania osadu za pomoca cieczy na osnowie jonowych (anionowych) i niejonowych SPCz. Nafta-Gaz 2019, 3, 38-48. [CrossRef]

21. Kremieniewski, M. Porównanie wyników metod pomiaru skuteczności usuwania osadu płuczkowego. Nafta-Gaz 2021, 1, 34-46. [CrossRef]

22. Jasiński, B. Ocena wpływu cieczy przemywającej na jakość zacementowania rur w otworze wiertniczym po użyciu płuczki glikolowo-potasowej. Nafta-Gaz 2016, 6, 413-421. [CrossRef]

23. Hirpa, M.M.; Arnipally, S.K.; Kuru, E. Effect of the Particle Size on the Near-Wall Turbulence Characteristics of the Polymer Fluid Flow and the Critical Velocity Required for Particle Removal from the Sand Bed Deposited in Horizontal Wells. Energies 2020, 13, 3172. [CrossRef]

24. Jamrozik, A.; Gonet, A.; Czekaj, L.; Fijał, J.; Ziaja, J.; Wiśniowski, R.; Stryczek, S. Salinity of drilling wastes as a factor determining their management. Przemyst Chem. 2017, 96, 972-976. [CrossRef]

25. Martin, M.; Latil, M. Mud Displacement by Slurry During Primary Cementing Jobs_Predicting Optimum Conditions; SPE: Houston, TX, USA, 1992.

26. Śliwa, T.; Stryczek, S.; Wysogląd, T.; Skakuj, A.; Wiśniowski RSapińska-Śliwa, A.; Bieda, A.; Kowalski, T. Wpływ grafitu i diatomitu na parametry wytrzymałościowe stwardniałych zaczynów cementowych. Przemyst Chem. 2017, 96, 960-963. [CrossRef]

27. Kremieniewski, M. Influence of Graphene Oxide on Rheological Parameters of Cement Slurries. Energies 2020, 13, 5441. [CrossRef]

28. Wiśniowski, R.; Skrzypaszek, K.; Małachowski, T. Selection of a Suitable Rheological Model for Drilling Fluid Using Applied Numerical Methods. Energies 2020, 13, 3192. [CrossRef]

29. Kremieniewski, M. Korelacja skuteczności działania środków dyspergujących o różnym mechanizmie upłynniania. Nafta-Gaz 2020, 11, 816-826. [CrossRef]

30. Adari, R.B.; Miska, S.; Kuru, E.; Bern, P.; Saasen, A. Selecting Drilling Fluid Properties and Flow Rates For Effective Hole Cleaning in High-Angle and Horizontal Wells. In Proceedings of the SPE Annual Technical Conference and Exhibition, Dallas, TX, USA, 1 October 2000. [CrossRef]

31. Kremieniewski, M. Hybrid Washer Fluid for Primary Cementing. Energies 2021, 14, 1295. [CrossRef]

32. Błaż, S. Nowe rodzaje cieczy przemywających osady z płuczki inwersyjnej przed zabiegiem cementowania otworów wiertniczych. Nafta-Gaz 2017, 5, 302-311. [CrossRef] 
33. Peterson, G. Die Haftung von Tiefbohrzementen bei Ringraum-zementatnion. Erdol Z. 1962, 1, 339-367.

34. Stryczek, S.; Gonet, A. Kierunki ograniczania migracji gazu z przestrzeni pierścieniowej otworu wiertniczego. WUG 2005, 3, 10-13.

35. Kremieniewski, M.; Rzepka, M. Wpływ superplastyfikatora na hydrofilowość zaczynów cementowych. Nafta-Gaz 2018, 10, 745-751. [CrossRef]

36. Kremieniewski, M.; Wiśniowski, R.; Stryczek, S.; Łopata, P. Comparison of Efficient Ways of Mud Cake Removal from Casing Surface with Traditional and New Agents. Energies 2021, 14, 3653. [CrossRef]

37. Kremieniewski, M.; Rzepka, M.; Kedzierski, M. Influence of the Contact Time of the Preflush Fluid with the Filter Cake on the Effectiveness of the Purification of the Annular Space. Nafta-Gaz 2018, 74, 29-36. [CrossRef]

38. Li, L.; Alegria, A.; Doan, A.A.; Kellum, M.G.; Hughes, B. A Novel Spacer System to Prevent Lost Circulation in Cementing Applications. In Proceedings of the 2016 AADE Fluids Technical Conference and Exhibition, Houston, TX, USA, 12-13 April 2016. Available online: https://www.aade.org/application/files/2715/7131/8487/AADE-16-FTCE-13_-_Li.pdf (accessed on 11 May 2021).

39. Li, L.; Padilla, F.; Doan, A.A.; Kellum, M.G.; Hughes, B. Evaluation of a New Spacer System Mixed On-The-Fly. In Proceedings of the 2016 AADE Fluids Technical Conference and Exhibition, Houston, TX, USA, 2016.

40. Ryan, D.F.; Browne, S.V.; Burnham, M.P. Mud Clean-Up in Horizontal Wells: A Major Joint Industry Study. In Proceedings of the SPE Annual Technical Conference and Exhibition, Dallas, TX, USA, 1 October 1995. [CrossRef]

41. Zamora Mario Jefferson, D.T.; Powell, J.W. Hole-Cleaning Study of Polymer-Based Drilling Fluids. In Proceedings of the SPE Annual Technical Conference and Exhibition, Houston, TX, USA, 1 October 1993. [CrossRef]

42. Kremieniewski, M. Korelacja wyników badań wytrzymałości na ściskanie i przyczepności do rur stalowych płaszcza cementowego z zaczynu o obniżonej gęstości. Nafta-Gaz 2019, 10, 613-624. [CrossRef]

43. Sanchez, R.A.; Azar, J.J.; Bassal, A.A.; Martins, A.L. The Effect of Drillpipe Rotation on Hole Cleaning During Directional Well Drilling. In Proceedings of the SPE/IADC Drilling Conference, Amsterdam, The Netherlands, 1 March 1997. [CrossRef]

44. Gbadamosi, A.O.; Junin, R.; Oseh, J.O.; Agi, A.; Yekeen, N.; Abdalla, Y.; Ogiriki, S.O.; Yusuff, A.S. Improving Hole Cleaning Efficiency using Nanosilica in Water-Based Drilling Mud. In Proceedings of the SPE Nigeria Annual International Conference and Exhibition, Lagos, Nigeria, 1 August 2018. [CrossRef]

45. Kremieniewski, M.; Kędzierski, M. Research into the development of a hybrid spacer. Nafta-Gaz 2020, 76, 517-526. [CrossRef]

46. Xu, D.; Guo, J.; Yuan, B.; Wen, D.; Fang, X.; Li, H.; Ling, B. A Minimum Volume Prediction of Spacer Based on Turbulent Dispersion Theory: Model and Example. Petroleum 2019, 5, 397-401. [CrossRef] 